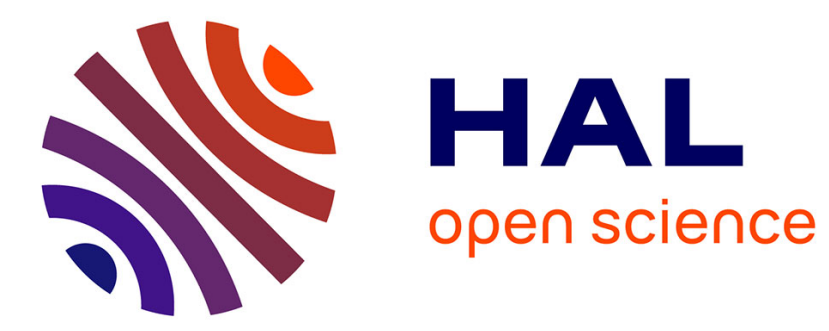

\title{
CeO 2 nanopowders as solid sorbents for efficient CO2 capture/release processes
}

Cedric Slostowski, Samuel Marre, Philippe Dagault, Odile Babot, Thierry Toupance, Cyril Aymonier

\section{To cite this version:}

Cedric Slostowski, Samuel Marre, Philippe Dagault, Odile Babot, Thierry Toupance, et al.. CeO 2 nanopowders as solid sorbents for efficient CO2 capture/release processes. Journal of CO2 Utilization, 2017, 20, pp.52-58. 10.1016/j.jcou.2017.03.023 . hal-01529387

\section{HAL Id: hal-01529387 \\ https://hal.science/hal-01529387}

Submitted on 30 May 2017

HAL is a multi-disciplinary open access archive for the deposit and dissemination of scientific research documents, whether they are published or not. The documents may come from teaching and research institutions in France or abroad, or from public or private research centers.
L'archive ouverte pluridisciplinaire HAL, est destinée au dépôt et à la diffusion de documents scientifiques de niveau recherche, publiés ou non, émanant des établissements d'enseignement et de recherche français ou étrangers, des laboratoires publics ou privés. 


\title{
$\mathrm{CeO}_{2}$ nano-powders as solid sorbents for efficient $\mathrm{CO}_{2}$ capture/release processes
}

Cedric Slostowski ${ }^{a}$, Samuel Marre ${ }^{a}$, Philippe Dagault ${ }^{\mathrm{a}}$, Odile Babot ${ }^{\mathrm{b}}$, Thierry Toupance ${ }^{\mathrm{b}}$, Cyril Aymonier ${ }^{\star, a}$

a CNRS, Univ. Bordeaux, ICMCB, UPR 9048, F-33600 Pessac (France)

b Institut des Sciences Moléculaires, Université de Bordeaux, UMR 5255 CNRS, C2M Team, 351 cours de la Libération, 33405 Talence (France)

\section{KEYWORDS}

Cerium oxide; $\mathrm{CO}_{2}$ capture; Adsorption; Solid sorbent; High specific surface area.

\begin{abstract}
Solid sorbents based on metal oxides have been investigated as an alternative to liquid sorbents for $\mathrm{CO}_{2}$ capture. Amongst them, acid-base properties of cerium oxide make it an excellent candidate for such applications at rather low temperature. In order to assess the suitability of this material, we quantified $\mathrm{CO}_{2}$ adsorption/desorption capacities at $25^{\circ} \mathrm{C}$ and 0.1 MPa by TGA technique. The adsorption results show the importance of a preliminary thermal treatment of the sorbents under inert gas, in order to maximize $\mathrm{CO}_{2}$ capture capacities via the thermal cleaning of $\mathrm{CeO}_{2}$ surface (atmospheric and synthetic pollutants) liberating the access to $\mathrm{CO}_{2}$ adsorption sites. $\mathrm{CO}_{2}$ capture capacities depend on the specific surface area of the cerium oxide powders, reaching a maximum of $50 \mathrm{mg}$ of $\mathrm{CO}_{2}$ adsorbed per gram of $\mathrm{CeO}_{2}$ displaying a specific surface area of $200 \mathrm{~m}^{2} \cdot \mathrm{g}^{-1}$. The study also demonstrates the partial reversibility of this adsorption at $25^{\circ} \mathrm{C}$ and its quantification, which can represent an important piece of information depending on the application (e.g., catalysis or $\mathrm{CO}_{2}$ capture). Finally, the $\mathrm{CO}_{2}$ adsorption/desorption cycling of our best material was investigated exhibiting promising results for the use of $\mathrm{CeO}_{2}$ powders as $\mathrm{CO}_{2}$ solid sorbent with moderate temperature-swing conditions (between $25^{\circ} \mathrm{C}$ and $150^{\circ} \mathrm{C}$ ).
\end{abstract}

\section{INTRODUCTION}

The reduction of greenhouse gases releases (e.g., carbon dioxide $-\mathrm{CO}_{2}$ ) has become an important challenge over the past 20 years, in order to reduce or prevent global warming and air pollution [1]. Several studies were conducted for selectively capturing $\mathrm{CO}_{2}$ at emission points (industries), then releasing it afterwards for its storage (CCS: Carbon Capture and Storage) or reutilizing it as a raw material [2-4]. Two main approaches can be distinguished concerning the reversible capture of $\mathrm{CO}_{2}$ : (i) the use of liquid adsorbents solutions and (ii) the use of solid adsorbents.

The first approach is used in most of today's industrial processes but presents several limitations (e.g., degradation of the liquid sorbent over temperature cycles causing regeneration costs) [5] that led industrials and scientists to look for alternative solutions via the use of solid sorbents, displaying various absorption capabilities (see Table 1 in the supporting information). From this perspective, new studies were conducted on the modification of the surface of materials by oxides (Cs, Ge, La, etc.) [6-8], or the utilization of these oxides alone [9-12], which displayed interesting properties for an efficient $\mathrm{CO}_{2}$ reversible capture [13-14]. Carbon dioxide indeed possesses the capacity to strongly interact with the surface of these oxides. Among them, cerium oxide $\left(\mathrm{CeO}_{2}\right)$ displays interesting acid-base properties, which have been extensively studied by Lavalley et al. [15-22].

Based on FTIR analyses during temperature cycles on $\mathrm{CeO}_{2}$ powders submitted to different gases, they showed that atmospheric pollutants (e.g., water or carbon dioxide) can easily adsorb over cerium oxide surfaces at room temperature (RT), due to the high surface reactivity, making this material an excellent candidate for $\mathrm{CO}_{2}$ capture (see Figure 1, 2 and Table 3 in the supplementary information). They demonstrated that the $\mathrm{CO}_{2}$ captured over $\mathrm{CeO}_{2}$ surface can adopt several configurations, each one of them displaying a different behavior over 
temperature increase $\left(\mathrm{CO}_{2}\right.$ release). [17] While some configurations will be desorbed at room temperature, some of them may require temperatures up to $500{ }^{\circ} \mathrm{C}$ to be released. Thus, knowing that atmospheric carbon dioxide can graft onto $\mathrm{CeO}_{2}$ surface at $\mathrm{RT}$, along with atmospheric water, it appears essential to thermally treat $\mathrm{CeO}_{2}$ powders at $500{ }^{\circ} \mathrm{C}$ under $\mathrm{N}_{2}$, in order to fully activate $\mathrm{CeO}_{2} \mathrm{NCs}$ surfaces prior to $\mathrm{CO}_{2}$ capture/release characterization. Several studies have been conducted in the past few years confirming or completing Lavalley et al. results [23-30].

While the interaction of cerium oxide with $\mathrm{CO}_{2}$ has been described and used in many catalytic reactions [31-35], the quantification of the adsorption capacity has not been extensively studied yet. Recently, Yoshikawa et al. described the synthesis and analysis of $\mathrm{CO}_{2}$ adsorbents based on cerium oxide, proposing for the first time a coherent quantification of the amount of $\mathrm{CO}_{2}$ adsorbed [36]. In their study, they compared the $\mathrm{CO}_{2}$ adsorption capacity of three different $\mathrm{CeO}_{2}$ powders with other $\mathrm{CO}_{2}$ adsorbents based on single-metal oxide, i.e. $\mathrm{SiO}_{2}, \mathrm{Al}_{2} \mathrm{O}_{3}$ and $\mathrm{ZrO}_{2}$. From their experimental results, several conclusions can be drawn concerning the important parameters to consider for $\mathrm{CO}_{2}$ adsorption capacity on metal oxide materials.

First of all, the presence of chemical adsorption sites for $\mathrm{CO}_{2}$ is obviously the most important parameter. Nevertheless, although $\mathrm{SiO}_{2}$ exhibited the highest specific surface area (more than $\left.800 \mathrm{~m}^{2} \cdot \mathrm{g}^{-1}\right)$, no $\mathrm{CO}_{2}$ was adsorbed on this surface. The authors also showed that $\mathrm{CeO}_{2}$-based materials exhibit the largest amount of $\mathrm{CO}_{2}$ adsorbed in comparison with the other selected oxides.

It appeared that the adsorption capacity of $\mathrm{CO}_{2}$ by $\mathrm{CeO}_{2}$ is dependent on several parameters. The synthesis conditions, and especially the precursor used for the synthesis of the oxide, can generate pollutants on the surface of the oxide preventing the chemical adsorption of $\mathrm{CO}_{2}$. Indeed, their materials synthesized from a chlorinated precursor displayed chloride pollutants over the surface, which they believe to reduce the adsorption capacity of the material (via the occupation of adsorption sites). Morphology, particle sizes, porosity and specific surface area of the materials are also important parameters determining the capture efficiency. Such parameters conditioned not only the number of adsorption sites available for the $\mathrm{CO}_{2}$ chemical adsorption but also the accessibility of these sites to $\mathrm{CO}_{2}$ molecules.

The more efficient material they tested towards the $\mathrm{CO}_{2}$ adsorption was a commercial highsurface-area $\mathrm{CeO}_{2}$ powder (specific surface are $-\mathrm{S}_{\text {spe }}=166 \mathrm{~m}^{2} \cdot \mathrm{g}^{-1}$ ) which is able to adsorb around $5.7 \mathrm{mg}$ of $\mathrm{CO}_{2}$ per gram of $\mathrm{CeO}_{2}\left(130 \mathrm{mmol} \cdot \mathrm{g}^{-1}\right)$ at $50{ }^{\circ} \mathrm{C}$. Their study also provided results similar to those of Lavalley et al. concerning the kind of carbonate species interacting with the surface of $\mathrm{CeO}_{2}$ during the adsorption and desorption of $\mathrm{CO}_{2}$.

Another study by $\mathrm{Li}$ et al. [36bis] reports the capture of $\mathrm{CO}_{2}$ on $\mathrm{CeO}_{2}$ nanopowders prepared by a surfactant-templated method over the $\mathrm{CO}_{2}$ absorption capacity at room temperature. The results obtained with pure $\mathrm{CeO}_{2}$ are slightly higher, namely: $700 \mathrm{mmol}^{-g^{-1}}$ (i.e. $\sim 30 \mathrm{mg} / \mathrm{g}$ ) for $\mathrm{S}_{\text {spe }}=181 \mathrm{~m}^{2} \cdot \mathrm{g}^{-1}$.

In our previous work, we described the fast and simple synthesis in near- and supercritical alcohols of $\mathrm{CeO}_{2}$ nanocrystals aggregated in bigger round shapes [37]. We showed that our powders can display high specific surface area - up to $200 \mathrm{~m}^{2} \cdot \mathrm{g}^{-1}$ - and keep their particular morphology, after a thermal treatment at $500{ }^{\circ} \mathrm{C}$, required to clean the surface of the $\mathrm{CeO}_{2}$ powders [38]. Thus, our $\mathrm{CeO}_{2}$ nanocrystals appear to be excellent candidates as $\mathrm{CO}_{2}$ solid adsorbents. In this work, we propose a method to quantify the adsorption and the desorption of $\mathrm{CO}_{2}$ over cerium oxide powders at $25^{\circ} \mathrm{C}$ and $0.1 \mathrm{MPa}$, and to draw a relation between the specific surface area of the powders and their $\mathrm{CO}_{2}$ adsorption capacity, while demonstrating that an appropriate thermal treatment of the $\mathrm{CeO}_{2}$ powders is of key importance in order to maximize the activity of $\mathrm{CeO}_{2}$ towards $\mathrm{CO}_{2}$ capture.

\section{EXPERIMENTAL SECTION}

Materials. The $\mathrm{CeO}_{2}$ powders used in this work were previously synthesized in our custombuilt continuous process and characterized, as described in our previous work [37]. As a reminder, they were synthesized from ammonium cerium nitrate in near- or supercritical alcohols: methanol (scMeOH), ethanol (scEtOH), propanol (scPrOH), butanol (scButOH), pentanol $(\mathrm{ncPentOH})$, hexanol $(\mathrm{ncHexOH})$ and isopropanol (sciPrOH). The experimental 
conditions were set at $300{ }^{\circ} \mathrm{C}$ and $24.5 \mathrm{MPa}$, with a residence time $\left(\mathrm{t}_{\mathrm{s}}\right)$ of $55 \mathrm{~s}$. The recovered dry powders were used as produced, without any post-treatment.

Three additional samples of $\mathrm{CeO}_{2}$ powders synthesized in near- and supercritical water were also studied as a matter of comparison with powders synthesized in alcohols [37]. The experimental conditions were set at $300{ }^{\circ} \mathrm{C}, 24.5 \mathrm{MPa}$ and $45 \mathrm{~s}$ for the first sample and 400 ${ }^{\circ} \mathrm{C}, 24.5 \mathrm{MPa}, 10 \mathrm{~s}$ and $45 \mathrm{~s}$ for the two other samples. The recovered dry powders were also used as produced.

All dry powders were grinded and sieved before further utilization.

The synthesis conditions, the crystallite sizes and the specific surface areas of the assynthesized $\mathrm{CeO}_{2}$ nanocrystals (NCs) are reminded in Table 2 of Supplementary information, along with their crystallite sizes and specific surface areas after $5 \mathrm{~h}$ of thermal treatment under $\mathrm{N}_{2}$.

The nitrogen flow was provided by the internal gas network in our laboratory, while the $\mathrm{CO}_{2}$ (purity $\geq 99.5 \%$ ) was purchased from Air Liquide and filtrated through a $\mathrm{SiO}_{2}$ sieve tank prior to utilization.

\section{Apparatus and procedure.}

Thermal treatment under $\mathrm{N}_{2}$ flow and $\mathrm{CO}_{2}$ capture quantification were both performed using a TGA apparatus equipped with a custom-built gas inlet. Approximately $100 \mathrm{mg}$ of $\mathrm{CeO}_{2}$ powders were placed in a Pt crucible, itself placed in a microbalance SETARAM mtb 10-8. A schematic representation of the apparatus is given in Figure 1. The 3-way valve allows switching from $\mathrm{N}_{2}$ to $\mathrm{CO}_{2}$ during TGA analysis.



Figure 1. Schematic representation of the TGA apparatus used for $\mathrm{CeO}_{2}$ powders thermal treatment under $\mathrm{N}_{2}$ flow (Gas path $\boldsymbol{A}$ ) and the quantification of $\mathrm{CO}_{2}$ capture over $\mathrm{CeO}_{2}$ nanopowders (Gas path $\boldsymbol{B}$ )

Prior to the $\mathrm{CO}_{2}$ capture quantification analysis, $\mathrm{CeO}_{2}$ powders are submitted to a thermal treatment under a $\mathrm{N}_{2}$ flow (Figure 1 - Gas path $\boldsymbol{A}$ ). First, the temperature is maintained for $1 \mathrm{~h}$ at room temperature (RT), in order to stabilize the microbalance atmosphere, before being 
raised at $5{ }^{\circ} \mathrm{C} \cdot \mathrm{min}^{-1}$ up to $500{ }^{\circ} \mathrm{C}$. Then, the temperature is kept constant $\left(500{ }^{\circ} \mathrm{C}\right)$ for $5 \mathrm{~h}$, before being finally decreased to $\mathrm{RT}$ at $5^{\circ} \mathrm{C} \cdot \mathrm{min}^{-1}$.

Once the temperature is back to $\mathrm{RT}, \mathrm{a} \mathrm{CO}_{2}$ flow is injected into the microbalance for $3 \mathrm{~h}$ at RT (Gas path $\boldsymbol{B}$ ), in order to quantify the $\mathrm{CO}_{2}$ capture over the $\mathrm{CeO}_{2}$ powders. Finally, the gas flow is switched back to $\mathrm{N}_{2}$ (Gas path $\boldsymbol{A}$ ), in order to quantify the $\mathrm{CO}_{2}$ desorption from the $\mathrm{CeO}_{2}$ surface.

Characterization techniques. Crystallite sizes $\left(d_{c r}\right)$ of the $\mathrm{CeO}_{2}$ nanocrystals were calculated using XRD patterns. The XRD patterns were recorded on a PANalytical X'Pert MPD powder diffractometer $\left(\theta-\theta\right.$ Bragg-Brentano geometry using $\mathrm{Cu} \mathrm{K}_{\mathrm{a} 1, \mathrm{\alpha} 2}\left(\lambda_{1}=1.54060 \AA, \lambda_{2}=1.54441\right.$ $\AA$ ) radiation, equipped with a secondary monochromator and a X'Celerator detector, in the range of $8-120^{\circ}$, in continuous scan mode at $3.5 \times 10^{-3}{ }^{\circ} \cdot \mathrm{s}^{-1}$. The powder was ground and sieved at $50 \mu \mathrm{m}$ before being subjected to XRD.

The texture of the $\mathrm{CeO}_{2}$ nanocrystals was analyzed by nitrogen adsorption isotherm $(77 \mathrm{~K})$ measurements. Data collection was performed by the static volumetric method, using an ASAP2010 apparatus (Micromeritics). Prior to each measurement, the samples were degassed at $150^{\circ} \mathrm{C}$ in vacuo for a time interval high enough to reach a constant pressure $(<10$ $\mu \mathrm{mHg}$ ). The BET equation was applied between 0.05 and 0.3 relative pressures to provide specific surface areas $\left(\mathrm{S}_{\mathrm{sp}}\right)$.

\section{RESULTS}

Characterization and quantification of the $\mathrm{CO}_{2}$ adsorption/desorption over thermally treated $\mathrm{CeO}_{2}$ powders synthesized in nc- or sc-alcohols. $\mathrm{CO}_{2}$ captured over $\mathrm{CeO}_{2}$ can adopt several configurations, as it has been demonstrated by Lavalley et al. [17] (see Figure 1 of Supplementary information). Depending on the configuration adopted by the $\mathrm{CO}_{2}$ over the $\mathrm{CeO}_{2}$ surface, its release may require temperatures up to $500{ }^{\circ} \mathrm{C}$. Knowing that atmospheric carbon dioxide can graft onto $\mathrm{CeO}_{2}$ surface at $\mathrm{RT}$, along with atmospheric water, it appears essential to thermally treat $\mathrm{CeO}_{2}$ powders at $500{ }^{\circ} \mathrm{C}$ under $\mathrm{N}_{2}$, in order to fully activate the $\mathrm{CeO}_{2} \mathrm{NCs}$ surfaces prior to $\mathrm{CO}_{2}$ capture/release characterization.

Thus, $\mathrm{CeO}_{2}$ powders were submitted to a $5 \mathrm{~h}$ thermal treatment at $500{ }^{\circ} \mathrm{C}$ under $\mathrm{N}_{2}$, as previously described, prior to the $\mathrm{CO}_{2}$ capture/release characterization. Once the temperature is back to RT, the $\mathrm{CeO}_{2}$ samples were submitted to a $\mathrm{CO}_{2}$ flow at RT (Figure 1 - Gas path $B$ ) for $3 \mathrm{~h}$, in order to quantify carbon dioxide adsorption over the $\mathrm{CeO}_{2}$ surfaces. Finally, gas is switched to $\mathrm{N}_{2}$ for $3 \mathrm{~h}$ at $\mathrm{RT}$, in order to quantify $\mathrm{CO}_{2}$ desorption from $\mathrm{CeO}_{2}$ surfaces. Weight losses of samples over such treatment cycle are followed by TGA measurements.

All the analyzed $\mathrm{CeO}_{2}$ powders adopted the same behavior when submitted to such treatment. A general representation of the behavior of these powders is given in Figure 2, along the gas/temperature program used.

During the preliminary thermal treatment under $\mathrm{N}_{2}$ flow, a drastic weight loss is observed. This phenomenon can be attributed to water and carbon dioxide desorption, which can graft easily at RT, but also to grafted alcohol desorption. Indeed, we previously showed that the alcohol used as solvent during the synthesis in near- or supercritical conditions acts as a surface modifier for the $\mathrm{CeO}_{2}$ surfaces [37,39], and tends to desorb in this temperature range [38].

Then, when $\mathrm{CO}_{2}$ is flown over the $\mathrm{CeO}_{2} \mathrm{NCs}$ at $\mathrm{RT}$, a gain in weight is observed, which is attributed to $\mathrm{CO}_{2}$ adsorption over the $\mathrm{CeO}_{2}$ surfaces. Finally, a weight loss is witnessed when atmosphere is switched back to $\mathrm{N}_{2}$ flow, corresponding to a partial desorption of $\mathrm{CO}_{2}$ from the $\mathrm{CeO}_{2}$ surfaces. 
Time



Figure 2. Representation of the general behavior for the weight loss of $\mathrm{CeO}_{2}$ powders monitored by TGA. The sample is treated under $\mathrm{N}_{2}$ at RT for $1 \mathrm{~h}$ then at $500{ }^{\circ} \mathrm{C}$ for $5 \mathrm{~h}(5$ ${ }^{\circ} \mathrm{C}$. $\left.\mathrm{min}^{-1}\right)$. Back to RT, the sample is submitted to a $\mathrm{CO}_{2}$ flow for $3 \mathrm{~h}$ then to a $\mathrm{N}_{2}$ flow for $3 \mathrm{~h}$. $\mathrm{m}_{\mathrm{s}}\left(\mathrm{t}_{\mathrm{o}}\right)$ : Initial weight of the sample when atmosphere is switched to $\mathrm{CO}_{2}$.

The adsorption capacity of $\mathrm{CO}_{2}$ for each sample as the function of time (Adsco2 $(\mathrm{t})$, in $\mathrm{mg}$ of $\mathrm{CO}_{2} / \mathrm{g}$ of $\mathrm{CeO}_{2}$, or $\mathrm{mg} / \mathrm{g}$ ) can be calculated from the TGA curves. The mass of the sample at the beginning of $\mathrm{CO}_{2}$ flow switch $\left(\mathrm{m}_{\mathrm{s}}\left(\mathrm{t}_{0}\right)\right.$, in $\left.\mathrm{mg}\right)$ is used as a reference (Figure 2). The mass of $\mathrm{CO}_{2}$ adsorbed by the $\mathrm{CeO}_{2}$ as a function of time ( $\mathrm{m}_{\mathrm{co} \text {-ads }}(\mathrm{t})$, in $\left.\mathrm{mg}\right)$ can be therefore obtained by subtracting the initial mass $\mathrm{m}_{\mathrm{s}}\left(\mathrm{t}_{0}\right)$ to the mass at the time $t\left(\mathrm{~m}_{\mathrm{s}}(\mathrm{t})\right.$, in $\left.\mathrm{mg}\right)$, as described by the Equation (1).

Thus, the adsorption capacity of $\mathrm{CO}_{2}$ by the sample as a function of time (Adsco2 $(\mathrm{t})$ ) is easily calculated as the ratio of the mass of $\mathrm{CO}_{2}$ adsorbed by the sample over the mass at $t_{0}$ (Equation (2)).

$$
\begin{aligned}
\mathrm{m}_{\mathrm{CO}_{2} \text {-ads }}(\mathrm{t}) & =\mathrm{m}_{\mathrm{s}}(\mathrm{t})-\mathrm{m}_{\mathrm{s}}\left(\mathrm{t}_{0}\right) \\
\operatorname{Ads}_{\mathrm{CO}_{2}}(\mathrm{t}) & =\frac{100 \cdot \mathrm{m}_{\mathrm{CO}_{2} \text {-ads }}(\mathrm{t})}{\mathrm{m}_{\mathrm{s}}\left(\mathrm{t}_{0}\right)}
\end{aligned}
$$

Based on these considerations, a general representation of the variation of the $\mathrm{CO}_{2}$ quantity adsorbed on the $\mathrm{CeO}_{2}$ surface as a function of time (Ads $\left.\mathrm{CO}_{2}(\mathrm{t})\right)$ is given in Figure 3 . Several observations and conclusions can be withdrawn from such curve.

First, as observed by Lavalley et al. [17], about $15 \mathrm{~min}$ are needed to reach the maximum $\mathrm{CO}_{2}$ adsorption quantity $\left(\mathrm{Ads} \max\right.$, in $\mathrm{mg} \mathrm{CO} / \mathrm{C} \mathrm{CeO}_{2}$ ). Such phenomenon is led by both the diffusion kinetics of $\mathrm{CO}_{2}$ in the material and the thermodynamics of $\mathrm{CO}_{2}-\mathrm{CeO}_{2}$ interactions.

When the atmosphere is switched from a $\mathrm{CO}_{2}$ to a $\mathrm{N}_{2}$ flow, a decrease of the adsorbed $\mathrm{CO}_{2}$ quantity is observed. Yet, this phenomenon is not only slower than the adsorption but also not complete, i.e. a considerable amount of $\mathrm{CO}_{2}$ remains adsorbed over $\mathrm{CeO}_{2}$ surfaces after several hours of $\mathrm{N}_{2}$ flow at $25^{\circ} \mathrm{C}$. Regarding the works of Lavalley et al., such phenomenon can easily be explained by the broad range of $\mathrm{CO}_{2}-\mathrm{CeO}_{2}$ interaction species forming during the adsorption at $25^{\circ} \mathrm{C}$ under a $\mathrm{CO}_{2}$ flow (Figure 1 of Supplementary information). Some of them will desorb spontaneously at $25{ }^{\circ} \mathrm{C}$ when the $\mathrm{CO}_{2}$ flow is stopped (i.e., 
hydrogenocarbonates and bridged carbonates mainly) while other will require temperatures up to $500^{\circ} \mathrm{C}$ to be desorbed (i.e., bidentate, monodentate and polydentate carbonates mainly).

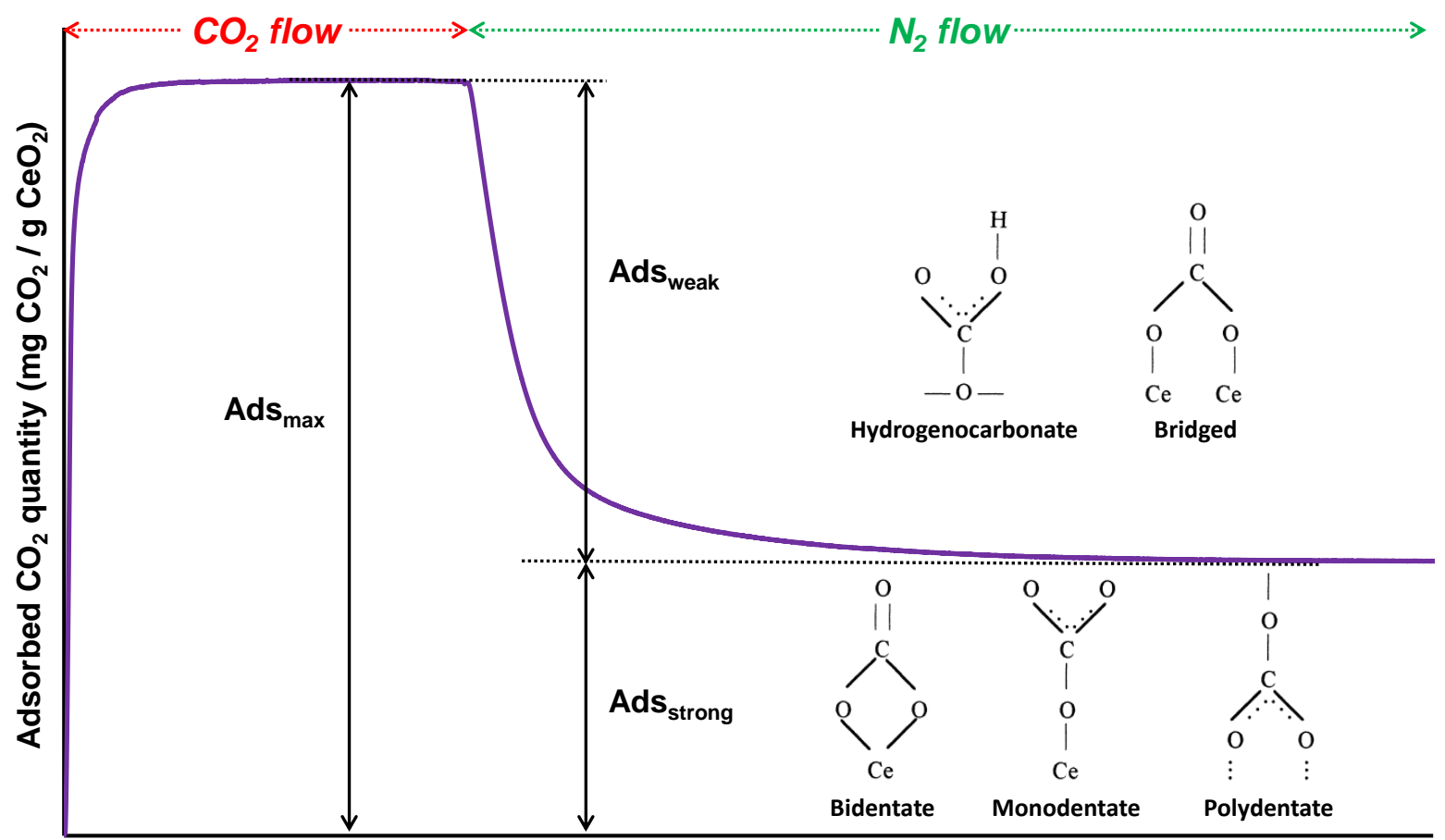

Time

Figure 3. General overview of the quantity of adsorbed $\mathrm{CO}_{2}$ over $\mathrm{CeO}_{2}$ samples as a function of time. Representations of the most probable configurations for $\mathrm{CO}_{2}-\mathrm{CeO}_{2}$ interactions are also pictured. Hydrogenocarbonates and bridged carboxylates are desorbed at $\mathrm{RT}$ under $\mathrm{N}_{2}$ flow (weak $\mathrm{CO}_{2}$ adsorption, Ads $_{\text {weak }}$ ). Bidentate, monodentate and polydentate carboxylates remains at the surface of $\mathrm{CeO}_{2}$ after $\mathrm{N}_{2}$ flow at $\mathrm{RT}$ (strong $\mathrm{CO}_{2}$ adsorption, Ads strong).

Thus, the maximum quantity of $\mathrm{CO}_{2}$ adsorbed can be considered as the sum of two kinds of $\mathrm{CO}_{2}$ interactions with $\mathrm{CeO}_{2}$ surface. First, the hydrogenocarbonates and bridged carbonates form weak interactions at $25^{\circ} \mathrm{C}$, and desorb by simply stopping the $\mathrm{CO}_{2}$ flow over the $\mathrm{CeO}_{2}$ samples. Those species can be quantified as the quantity of $\mathrm{CO}_{2}$ desorbed from $\mathrm{CeO}_{2}$ surfaces during the purge at $25^{\circ} \mathrm{C}\left(\mathrm{Ads}_{\text {weak, }}\right.$, in $\mathrm{mg} \mathrm{CO} / \mathrm{g} \mathrm{CeO}_{2}$, or $\left.\mathrm{mg} / \mathrm{g}\right)$. Then, bidentate, monodentate and polydentate carbonates create a strong interaction with $\mathrm{CeO}_{2}$ surfaces and cannot be desorbed from these surfaces at $25^{\circ} \mathrm{C}$. They can be quantified as the quantity of $\mathrm{CO}_{2}$ still adsorbed over $\mathrm{CeO}_{2}$ surfaces during the purge at $25^{\circ} \mathrm{C}\left(\mathrm{Ads}_{\text {strong, }}\right.$, in $\mathrm{mg} \mathrm{CO}_{2} / \mathrm{g} \mathrm{CeO}_{2}$, or $\left.\mathrm{mg} / \mathrm{g}\right)$. Such differentiation can be very useful for applications such as $\mathrm{CO}_{2}$ storage, which may require a stable adsorption even when $\mathrm{CO}_{2}$ flow is stopped (i.e., Ads strong) or which may require $\mathrm{CO}_{2}$ desorption at low temperatures (Ads weak $_{\text {) }}$, depending on the utilization.

The experimental values of $\mathrm{Ads}_{\max }$ and $\mathrm{Ads}_{\text {strong }}$ are plotted as a function of the $\mathrm{CeO}_{2} \mathrm{NCs}$ specific surface area in Figure 4 (The exact values can be found in Table 3 of the Supplementary information, along with those of the Ads weak).

The cerium oxide powders synthesized in near- and supercritical alcohols allow reaching a maximum quantity of adsorbed $\mathrm{CO}_{2}$ up to $48 \mathrm{mg} / \mathrm{g}$ of $\mathrm{CeO}_{2}$, for samples developing high specific surface areas. 




Figure 4. Experimental values of the Ads $\max$ and the $\mathrm{Ads}_{\text {strong }}$ as a function of the surface specific areas of the $\mathrm{CeO}_{2}$ powders thermally treated at $500{ }^{\circ} \mathrm{C}$ under $\mathrm{N}_{2}$ flow. Squares are $\mathrm{CeO}_{2}$ powders synthesized in nc- or sc-alcohols and circles the ones synthesized in nc- or sc-water.

$\mathrm{CeO}_{2}$ powders synthesized in near- and supercritical water have also been submitted to the same $\mathrm{N}_{2}$ thermal treatment at $500{ }^{\circ} \mathrm{C}$ and $\mathrm{CO}_{2}$ adsorption/desorption cycle at RT. Similar behaviors are observed and the measured Ads max validate that it exists a relationship between the quantity of $\mathrm{CO}_{2}$ adsorbed over $\mathrm{CeO}_{2}$ surfaces and the specific surface area, disregarding their syntheses conditions. The Ads $\max$ and Ads strong of these samples as a function of their specific surface areas are presented in Figure 4, along with the results with alcohols (The exact values can also be found in Table 4 of the Supplementary information, along with those of the Ads weak).

\section{DISCUSSION}

Concerning the $\mathrm{CO}_{2}$ adsorption capacity of the thermally treated $\mathrm{CeO}_{2} \mathrm{NCs}$, the TGA analyses under $\mathrm{CO}_{2}$ flow at $25^{\circ} \mathrm{C}$ showed that the maximum quantity of $\mathrm{CO}_{2}$ adsorbed on the surface of $\mathrm{CeO}_{2} \mathrm{NCs}$ increases linearly with the specific area of $\mathrm{CeO}_{2}$ powders in the range $0-150$ $\mathrm{m}^{2} \cdot \mathrm{g}^{-1}$. This work is the first demonstration of such a relationship between $\mathrm{CO}_{2}$ adsorption capacity over $\mathrm{CeO}_{2}$ and specific surface area.

However, we noticed that this adsorption reaches its limits at $48 \mathrm{mg}$ of $\mathrm{CO}_{2}$ captured by gram of $\mathrm{CeO}_{2}$ powders (synthesized in $\mathrm{ncHexOH}$ ). But this limit appears at high specific areas, when ButOH, PentOH and $\mathrm{HexOH}$ are used for the synthesis. Now, we previously showed that not all organic species are desorbed from such $\mathrm{CeO}_{2}$ samples at $500^{\circ} \mathrm{C}$, which limits their specific surface areas but also makes a hard path for $\mathrm{CO}_{2}$ diffusion through the round shaped structures.

Playing with thermal treatment to increase the adsorption rates. Our previous work showed that a treatment under $\mathrm{N}_{2}$ flow at a temperature higher than $500{ }^{\circ} \mathrm{C}$ can enhance the desorption of organic species and thus leads to $\mathrm{CeO}_{2} \mathrm{NCs}$ with higher specific surface areas [38]. Nonetheless, a temperature too important can also lead to sintering which will have the opposite effect, i.e. a decrease of the specific surface areas of the materials.

This treatment temperature also plays an important role to improve the $\mathrm{CO}_{2}$ adsorption capacities of the $\mathrm{CeO}_{2}$ powders, alongside with the specific surface areas of the materials. As previously shown, the $\mathrm{CeO}_{2} \mathrm{NCs}$ synthesized in ncHexOH reach a $\mathrm{S}_{\mathrm{sp}}$ of $182 \mathrm{~m}^{2} \cdot \mathrm{g}^{-1}$ and display 
an $\mathrm{Ads}$ max of $47.9 \mathrm{mg} / \mathrm{g}$ after a thermal treatment at $500{ }^{\circ} \mathrm{C}$. When submitted to a thermal treatment at $540{ }^{\circ} \mathrm{C}$, the $S_{s p}$ of these materials increases from 182 to $199 \mathrm{~m}^{2} . \mathrm{g}^{-1}$ owing to a better desorption of surface pollutants and the Ads $\max$ also increases alongside from $47.9 \mathrm{mg} / \mathrm{g}$ versus $49.6 \mathrm{mg} / \mathrm{g}$. On the contrary, the $\mathrm{CeO}_{2} \mathrm{NCs}$ exposed to a thermal treatment at $600{ }^{\circ} \mathrm{C}$ undergo sintering and thus, the $S_{s p}$ of these materials decreases (from $199 \mathrm{~m}^{2} . \mathrm{g}^{-1}$ to $185 \mathrm{~m}^{2} . \mathrm{g}^{-}$

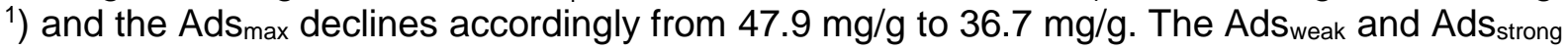
of these materials are given in the Table 5 of Supplementary information.

These results show the importance of choosing an appropriate temperature for the thermal activation of the $\mathrm{CeO}_{2}$ (mandatory to remove surface pollutants and thus activate the material towards $\mathrm{CO}_{2}$ capture) prior to their use for $\mathrm{CO}_{2}$ capture.

Cyclability of the $\mathrm{CeO}_{2}$ powders. We have further investigated the suitability of our materials as potential $\mathrm{CO}_{2}$ solid sorbents by checking their cyclability. Indeed, we showed that our materials can display high specific surface area and interesting $\mathrm{CO}_{2}$ adsorption capacity at low temperature $\left(25^{\circ} \mathrm{C}\right.$ and $\left.0.1 \mathrm{MPa}\right)$, but to be suitable as $\mathrm{CO}_{2}$ solid sorbents, they need to be regenerable for continuous use with an acceptable thermal treatment cycle.

In this regard, a longer experiment was led on crude $\mathrm{CeO}_{2}$ powders synthesized in ncHexOH with $3 \mathrm{CO}_{2}$ adsorption tests and different regeneration steps under $\mathrm{N}_{2}$. The weight loss of the sample and thus, its $\mathrm{CO}_{2}$ adsorption/desorption during this experiment were followed by TGA and the results are presented in Figure 5, along with the experimental conditions (temperature, time and gas flow). Numerical values of these results are also given in Table 1.

The first step was a classical thermal treatment at $500{ }^{\circ} \mathrm{C}$ under $\mathrm{N}_{2}$ flow in order to eliminate pollutants from the surface of $\mathrm{CeO}_{2}$ powders, resulting in a weight loss from the sample $(-12.7$ $\%)$. Of course, this temperature is not sufficient to achieve a complete desorption of the pollutants, as previously demonstrated, but allows avoiding the sintering of the powders. Once the sample is back to RT, the gas flow was switched to $\mathrm{CO}_{2}$ (Step 2), which resulted in a gain of weight of the sample (+3.8\%), corresponding to an adsorption of $44.0 \mathrm{mg}$ of $\mathrm{CO}_{2}$ per gram of $\mathrm{CeO}_{2}$, which is comparable to the value previously obtained with similar treatment and samples (Table 2 of Supplementary information).

In a third step, gas flow was switched back to $\mathrm{N}_{2}$ to characterize the $\mathrm{CO}_{2}$ desorption from the sample at $25{ }^{\circ} \mathrm{C}$. It resulted in a weight loss of the sample (- $\left.2.0 \%\right)$ corresponding to a $\mathrm{CO}_{2}$ desorption of $24.0 \mathrm{mg} / \mathrm{g}$, which is in good agreement with previous experiments.

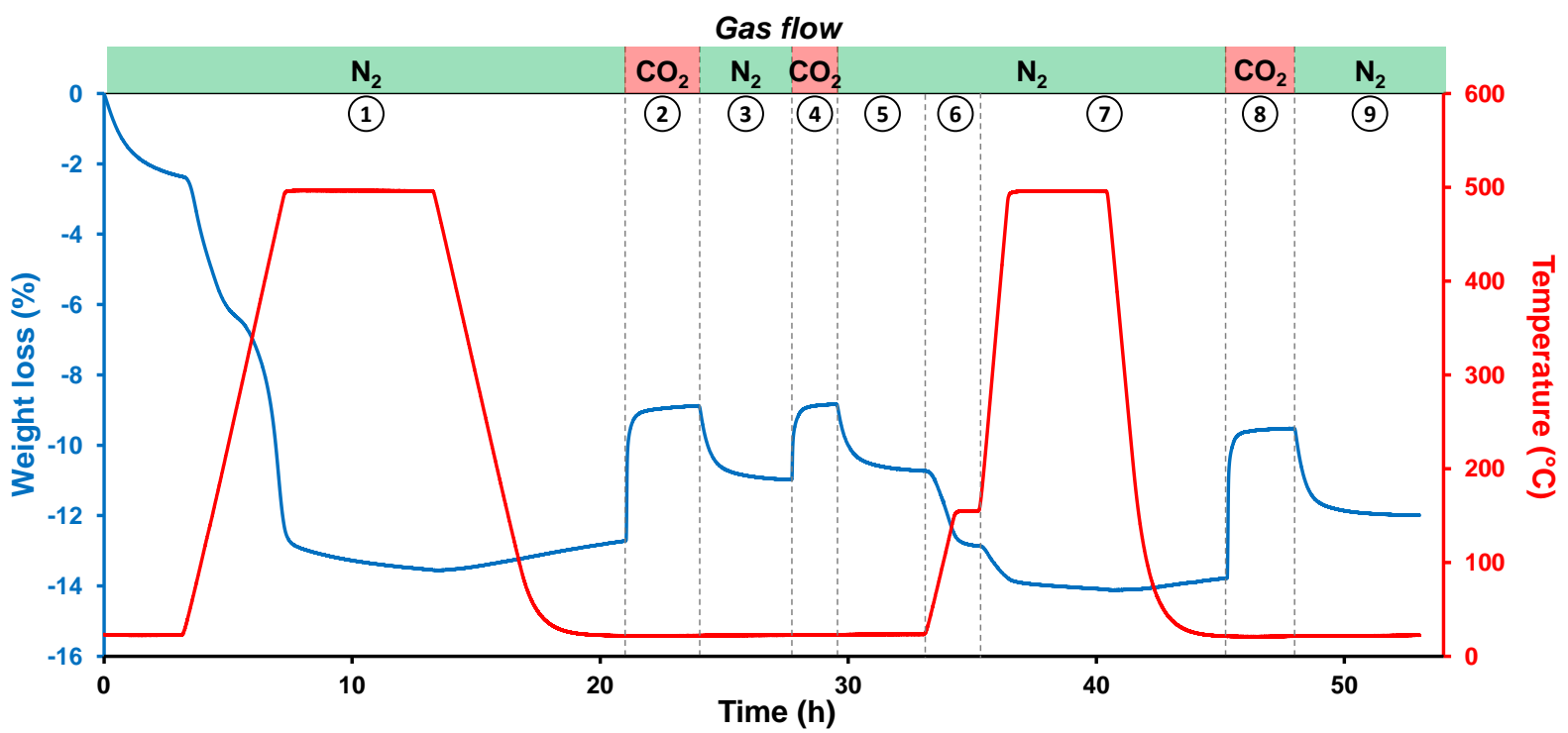

Figure 5. Experimental conditions and weight loss of $\mathrm{CeO}_{2}$ powders synthesized in $\mathrm{ncHexOH}$ and submitted to cycling tests of $\mathrm{CO}_{2}$ adsorption/desorption.

Another $\mathrm{CO}_{2}$ adsorption/desorption cycle at $\mathrm{RT}$ was then performed in order to compare the values of $\mathrm{Ads}_{\text {weak }}$ for pristine and reused $\mathrm{CeO}_{2}$ powder (Step 4). A gain of weight of $+2.0 \%$ was witnessed corresponding to an adsorption of $24.4 \mathrm{mg}$ of $\mathrm{CO}_{2}$ per gram of $\mathrm{CeO}_{2}$. This 
means that all the $\mathrm{CO}_{2}$ that was desorbed during the previous step under $\mathrm{N}_{2}$ at $25^{\circ} \mathrm{C}$ can be adsorbed again at the $\mathrm{CeO}_{2}$ surface, i.e. there is no loss of $\mathrm{CO}_{2}$ adsorption capacity after a desorption step at $25^{\circ} \mathrm{C}$. This $\mathrm{CO}_{2}$ is once again desorbed under $\mathrm{N}_{2}$ flow at $25^{\circ} \mathrm{C}$ during a fifth step (weight loss of $-1.9 \%$, i.e. a $\mathrm{CO}_{2}$ desorption of $22.6 \mathrm{mg} / \mathrm{g}$ during this step). This may mean that each $\mathrm{CeO}_{2}$ adsorption sites will favor a specific type of interaction for the capture of $\mathrm{CO}_{2}$ (e.g., hydrogenocarbonate or bidentate carbonate) which remains the same over cycling.

Table 1. Cycling experiments performed on the $\mathrm{CeO}_{2}$ powders synthesized in $\mathrm{ncHexOH}$.

\begin{tabular}{|c|c|c|c|c|c|}
\hline Step & Gas & $\mathrm{T}\left({ }^{\circ} \mathrm{C}\right)$ & $\begin{array}{l}\text { Duration } \\
\text { (h) }\end{array}$ & $\begin{array}{c}\text { Total weight loss } \\
(\%)^{[a]}\end{array}$ & $\begin{array}{c}\Delta \operatorname{Ads}\left(\mathrm{CO}_{2}\right) \\
(\mathrm{mg} / \mathrm{g})^{[\mathrm{bb}]}\end{array}$ \\
\hline \multirow{5}{*}{1} & \multirow{5}{*}{$\mathrm{N}_{2}$} & 25 & 3 & \multirow{5}{*}{-12.7} & \multirow{5}{*}{-} \\
\hline & & 25 to 500 & 4 & & \\
\hline & & 500 & 6 & & \\
\hline & & 500 to 25 & 7 & & \\
\hline & & 25 & 1 & & \\
\hline 2 & $\mathrm{CO}_{2}$ & 25 & 3 & -8.9 & +44.0 \\
\hline 3 & $\mathrm{~N}_{2}$ & 25 & 4 & -10.9 & -24.0 \\
\hline 4 & $\mathrm{CO}_{2}$ & 25 & 2 & -8.9 & +24.4 \\
\hline 5 & $\mathrm{~N}_{2}$ & 25 & 4 & -10.8 & -22.6 \\
\hline \multirow{2}{*}{6} & \multirow{2}{*}{$\mathrm{N}_{2}$} & 25 to 150 & 1 & \multirow{2}{*}{-12.9} & \multirow{2}{*}{-24.2} \\
\hline & & 150 & 1 & & \\
\hline \multirow{4}{*}{7} & \multirow{4}{*}{$\mathrm{N}_{2}$} & 150 to 500 & 2 & \multirow{4}{*}{-13.7} & - \\
\hline & & 500 & 4 & & - \\
\hline & & 500 to 25 & 4 & & - \\
\hline & & 25 & 1 & & - \\
\hline 8 & $\mathrm{CO}_{2}$ & 25 & 3 & -9.5 & +49.3 \\
\hline 9 & $\mathrm{~N}_{2}$ & 25 & 5 & -12.0 & -20.7 \\
\hline
\end{tabular}

[a] Total weight loss of the material recorded from the beginning of the experiment by TGA.

${ }^{[b]}$ Calculated values of the adsorption (positive values) and desorption (negative values) of $\mathrm{CO}_{2}$ by $\mathrm{CeO}_{2}$ powders, deduced from the total weight loss values. The $\triangle A d s\left(\mathrm{CO}_{2}\right)$ values are cumulative, which means that after the Step 3, for example, $24.0 \mathrm{mg}$ of $\mathrm{CO}_{2}$ per gram of $\mathrm{CeO}_{2}$ are desorbed $\left(\mathrm{Ads}_{\text {weak }}=24\right.$ mg. $\left.\mathrm{g}^{-1}\right)$ while $(+44.0+(-24.0)=) 20.0 \mathrm{mg}$ of $\mathrm{CO}_{2}$ per gram of $\mathrm{CeO}_{2}$ remain on $\mathrm{CeO}_{2}$ powders (Ads strong $\left.=20 \mathrm{mg} \cdot \mathrm{g}^{-1}\right)$.

A desorption temperature of $25^{\circ} \mathrm{C}$ is obviously not sufficient enough to desorb all the $\mathrm{CO}_{2}$ captured by the $\mathrm{CeO}_{2}$ powders. Indeed, the work of Lavalley et al. showed that the $\mathrm{CO}_{2}$ species adsorbed at the surface of $\mathrm{CeO}_{2}$ can require temperatures up to $500^{\circ} \mathrm{C}$ to be desorbed [17]. A temperature difference of $475^{\circ} \mathrm{C}$ (between $25^{\circ} \mathrm{C}$ for the $\mathrm{CO}_{2}$ adsorption and $500{ }^{\circ} \mathrm{C}$ for the $\mathrm{CO}_{2}$ desorption) would hardly make $\mathrm{CeO}_{2}$ suitable as a solid sorbent from an energy point of view compared to classical use of liquid monoethanolamine, which can adsorb $\mathrm{CO}_{2}$ at $25{ }^{\circ} \mathrm{C}$ and can be regenerated at $150{ }^{\circ} \mathrm{C}$. Fortunately, not all $\mathrm{CO}_{2}$ species required temperature of $500{ }^{\circ} \mathrm{C}$ to desorb and some of the species, which do not desorb at RT, could be desorbed around $150^{\circ} \mathrm{C}$, according to the work Lavalley et al..

In order to check what could be the desorption efficiency with a thermal treatment at $150{ }^{\circ} \mathrm{C}$ (comparable to conventional liquid sorbent desorption process), a sixth step was performed under $\mathrm{N}_{2}$ with a $1 \mathrm{~h}$ threshold at $150^{\circ} \mathrm{C}$. A weight loss of $-2.1 \%$ is observed during this step, corresponding to a $\mathrm{CO}_{2}$ desorption of $24.2 \mathrm{mg} / \mathrm{g}$. Unexpectedly, this temperature increase from $25^{\circ} \mathrm{C}$ to $150{ }^{\circ} \mathrm{C}$ under $\mathrm{N}_{2}$ flow allows retrieving the weight of $\mathrm{CeO}_{2}$ in presence after the initial 
$\mathrm{N}_{2}$ thermal treatment $\left(500^{\circ} \mathrm{C}\right)$ and before the two $\mathrm{CO}_{2} / \mathrm{N}_{2}$ cycles at $25^{\circ} \mathrm{C}$. This means that the amount of $\mathrm{CO}_{2}$ species present at the surface in the $\mathrm{CeO}_{2}$ powders, which requires a thermal treatment over $150^{\circ} \mathrm{C}$, is negligible. Thusly, $\mathrm{CeO}_{2}$ powders would make great candidate at low temperature as $\mathrm{CO}_{2}$ solid sorbent for replacing liquid adsorbent systems.

Then, a seventh step was performed under $\mathrm{N}_{2}$ flow with a $4 \mathrm{~h}$ threshold at $500{ }^{\circ} \mathrm{C}$, witnessing a weight loss of $-0.8 \%$ after the temperature is back to RT. This weight loss is attributed to desorption of remaining organic species from the synthesis (alcohol grafts). This hypothesis is confirmed by the gain in weight $(+4.2 \%$ ) observed during a final step (Step 8$)$ under $\mathrm{CO}_{2}$ at $25^{\circ} \mathrm{C}$ (Step 8), which corresponds to a $\mathrm{CO}_{2}$ adsorption of $49.3 \mathrm{mg} / \mathrm{g}$. This adsorption capacity is higher than the one recorded after the first $\mathrm{CO}_{2}$ adsorption (Step 2, $44.0 \mathrm{mg} / \mathrm{g}$ ), which is coherent with the previous hypothesis. Indeed, not all the organic species from the synthesis are desorbed during the first step at $500{ }^{\circ} \mathrm{C}$ under $\mathrm{N}_{2}$, which limits the $\mathrm{CO}_{2}$ adsorption capacity of the material. During this second threshold at $500^{\circ} \mathrm{C}$ (Step 7), more surface pollutants are removed from the surface creating more available adsorption sites for $\mathrm{CO}_{2}$ and thus increasing the maximum $\mathrm{CO}_{2}$ adsorption capacity of the $\mathrm{CeO}_{2}$ powders.

In brief, cerium oxide powders with high specific surface areas appear as great candidates for temperature-swing reversible capture of $\mathrm{CO}_{2}$ at low temperature - between 25 and $150{ }^{\circ} \mathrm{C}-$ compared to most of the other metal oxides studied so far, which required higher temperatures for cyclability (e.g., $\mathrm{CaO} / \mathrm{CaCO}_{3}$ between 700 and $\left.800{ }^{\circ} \mathrm{C}[2,40]\right)$. This dramatically enhances the energy efficiency of the process.

\section{CONCLUSION}

The suitability of $\mathrm{CeO}_{2}$ materials as $\mathrm{CO}_{2}$ solid sorbent has been examined on powders displaying a large array of different specific surface areas (from 12 up to $199 \mathrm{~m}^{2} \cdot \mathrm{g}^{-1}$ ). This study showed that the adsorption efficiency of the $\mathrm{CeO}_{2}$ materials is primarily dependent on its specific surface area, with an almost linear relationship.

The adsorption of $\mathrm{CO}_{2}$ requiring the access of $\mathrm{CO}_{2}$ to the surface atoms of $\mathrm{CeO}_{2}$, we also showed that a thermal activation of the materials before their use as a solid sorbent is mandatory. This thermal treatment requires knowing well the material in order to wisely choose the operating temperature and thusly, maximize the $\mathrm{CO}_{2}$ capture capacity of the materials. Indeed, the preliminary treatment temperature must respect two major conditions: (i) being high enough to remove most of the surface pollutants from the material (e.g., atmospheric water and $\mathrm{CO}_{2}$ and synthesis residues), which are blocking potential $\mathrm{CO}_{2}$ adsorption sites and (ii) being low enough to avoid the sintering of the material, which will drastically decrease the $\mathrm{CO}_{2}$ adsorption capacity of the material along with its specific surface area [38].

This way, our $\mathrm{CeO}_{2}$ powders, displaying a specific surface area of $199 \mathrm{~m}^{2} . \mathrm{g}^{-1}$ after a thermal treatment at $540{ }^{\circ} \mathrm{C}$ under $\mathrm{N}_{2}$ flow, exhibited at $25^{\circ} \mathrm{C}$ and $0.1 \mathrm{MPa}$ a maximal $\mathrm{CO}_{2}$ adsorption capacity around $50 \mathrm{mg}$ of $\mathrm{CO}_{2}$ per gram of $\mathrm{CeO}_{2}$ (i.e., around $1130 \mathrm{mmol}$ of $\mathrm{CO}_{2} / \mathrm{kg}$ of $\mathrm{CeO}_{2}$ ). It was also demonstrated that the adsorption of $\mathrm{CO}_{2}$ by $\mathrm{CeO}_{2}$ is partially reversible at $25{ }^{\circ} \mathrm{C}$ and gave a quantification of the $\mathrm{CeO}_{2}-\mathrm{CO}_{2}$ species that can be desorbed just by stopping the $\mathrm{CO}_{2}$ flow and those which remains at the surface. Such distinction may be of key importance depending on the sought application for this material, e.g. catalysis requiring weak adsorption or capture requiring strong adsorption.

Eventually, the possible $\mathrm{CO}_{2}$ adsorption/desorption cycling over $\mathrm{CeO}_{2}$ powders has been examined. The preliminary analyses show that it is possible to adsorb $\mathrm{CO}_{2}$ at $25{ }^{\circ} \mathrm{C}$ and to regenerate almost completely the material at $150{ }^{\circ} \mathrm{C}$ under inert gas atmosphere, without losing the $\mathrm{CO}_{2}$ capture capacity. That way, we believe that high specific surface area $\mathrm{CeO}_{2}$ materials can be future great candidates as reversible low temperature $\mathrm{CO}_{2}$ solid sorbents (25 $-150^{\circ} \mathrm{C}$ ), making them competitive alternative to conventional liquid sorbents systems.

\section{AUTHOR INFORMATION Corresponding Author}

*Mailing address: ICMCB-CNRS, 87 Avenue du Dr Albert Schweitzer, 33608 Pessac Cedex, France. E-mail: cyril.aymonier@icmcb.cnrs.fr 


\section{Notes}

The authors declare no competing financial interest.

\section{ACKNOWLEDGMENTS}

The authors acknowledge the "Conseil Régional d'Aquitaine" for funding the PhD grant of C. Slostowski.

\section{REFERENCES}

[1] IPCC, 2014: Climate Change 2014: Synthesis Report. Contribution of Working Groups I, II and III to the Fifth Assessment Report of the Intergovernmental Panel on Climate Change. IPCC, Geneva, Switzerland, $151 \mathrm{pp}$.

[2] S. Choi, J. H. Drese, C. W. Jones, ChemSusChem 2 (2009) 796-854

[3] H. Yang, Z. Xu, M. Fan, R. Gupta, R. B. Slimane, A. E. Bland, I. Wright, J. Environ. Sci. 20 (2008), 14-27

[4] S.-Y. Lee, S.-Y. Park, J. Ind. Eng. Chem. 23 (2015) 1-11

[5] C.-H. Yu, C.-H. Huang, C.-S. Tan, Aerosol Air Qual. Res. 12 (2012) 745-769

[6] J. Chang Kim, H.-X. Li, C.-Y. Chen, M. Davis. Microporous Mater. 2 (1994) 413-423

[7] P. Hathaway, M. Davis. J. Catal. 116 (1989) 263-278

[8] R. Roque-Malherbe, R. Polanco-Estrella, F. Marquez-Linares. J. Phys. Chem. C 114 (2010) 17773-17787

[9] F. Garcia-Labiano, A. Abad, L. de Diego, P. Gayan, J. Adanez. Chem. Eng. Sci. 57 (2002) 2381-2393

[10] Y. Lin, Q. Yang, J. Ida. J. Taiwan Inst. Chem. Eng. 40 (2009) 276-280

[11] W. Liu, N. Low, B. Feng, G. Wang, J. Diniz Da Costa. Environ. Sci. Technol. 44 (2010) 841-847

[12] C.-H. Huang, K.-P. Chang, C.-T. Yu, P.-C. Chiang, C.-F. Wang. Chem. Eng. J. 161 (2010) 129-135

[13] R. Bal, B. Tope, T. Das, S. Hegde, S. Sivasanker. J. Catal. 204 (2001) 358-363

[14] J.-C. Lavalley, Catal. Today 27 (1996) 377-401

[15] C. Binet, A. Badri, M. Boutonnet-Kizling, J.-C. Lavalley. J. Chem. Soc., Faraday Trans. 90 (1994) 1023-1028

[16] M. Daturi, C. Binet, J.-C. Lavalley, H. Vidal, J. Kaspar, M. Graziani, G. Blanchard. J. Chim. Phys. Phys.-Chim. Biol. 95 (1998) 2048-2060

[17] C. Binet, M. Daturi, J.-C. Lavalley. Catal. Today 50 (1999) 207-225

[18] M. Daturi, C. Binet, J.-C. Lavalley, A. Galtayries, R. Sporken. Phys. Chem. Chem. Phys. 1 (1999) 5717-5724

[19] M. Daturi, E. Finocchio, C. Binet, J.-C. Lavalley, F. Fally, V. Perrichon. J. Phys. Chem. B 103 (1999) 4884-4891

[20] M. Daturi, C. Binet, J.-C. Lavalley, G. Blanchard. Surf. Interface Anal. 30 (2000) 273-277 [21] M. Daturi, E. Finocchio, C. Binet, J.-C. Lavalley, F. Fally, V. Perrichon, H. Vidai, N. Hickey, J. Kaspar. J. Phys. Chem. B 104 (2000) 9186-9194

[22] C. Binet, M. Daturi. Catal. Today 70 (2001) 155-167

[23] J. Stubenrauch, E. Brosha, J. Vohs, Catal. Today 28 (1996) 431-441

[24] K. Hadjiivanov, G. Vayssilov, Adv. Catal. 47 (2002) 307-511

[25] G. Jacobs, L. Williams, U. Graham, G. Thomas, D. Sparks, B. Davis, Appl. Catal., A 252 (2003) 107-118

[26] M. Swanson, V. Pushkarev, V. Kovalchuk, J. D'itri, Catal. Lett. 116 (2007) 41-45

[27] W. Gordon, Y. Xu, D. Mullins, S. Overbury. Phys. Chem. Chem. Phys. 11 (2009) 1117111183

[28] Y. Lykhach, T. Staudt, R. Streber, M. Lorenz, A. Bayer, H.-P. Steinruck, J. Libuda, Eur. Phys. J. B 75 (2010) 89-100

[29] G. Vayssilov, M. Mihaylov, P. Petkov, K. Hadjiivanov, K. Neyman, J. Phys. Chem. C 115 (2011) 23435-23454

[30] Y. Zhai, S. Zhang, H. Pang, Mater. Lett. 61 (2007) 1863-1866

[31] A. Trovarelli, Catal. Rev. 38 (1996) 439-520 
[32] R. Juarez, P. Concepcion, A. Corma, H. Garcia, Chem. Commun. 46 (2010) 4181-4183

[33] K. Rao, B. Reddy, S.-E. Park, Appl. Catal., B 100 (2010) 472-480

[34] K. Reed, A. Cormack, A. Kulkarni, M. Mayton, D. Sayle, F. Klaessig, B. Stadler, Environ. Sci.: Nano 1 (2014) 390-405

[35] C. Walkey, S. Das, S. Seal, J. Erlichman, K. Heckman, L. Ghibelli, E. Traversa, J. F. McGinnis, W. T. Self, Environ. Sci.: Nano 2 (2015) 33-53

[36] K. Yoshikawa, H. Sato, M. Kaneeda, J. N. Kondo, J. CO 2 Util. 8 (2014) 34-38.

[36bis] M. Li, U. Tumuluri, Z. Wu, S. Dai, ChemSusChem, 2015, 8, 3651-3660

[37] C. Slostowski, S. Marre, O. Babot, T. Toupance, C. Aymonier, Langmuir 28 (2012) 1665616663.

[38] C. Slostowski, S. Marre, O. Babot, T. Toupance, C. Aymonier, ChemPhysChem (2015), doi:10.1002/cphc.201500570 in press

[39] C. Slostowski, S. Marre, O. Babot, T. Toupance, C. Aymonier, Langmuir 30 (2014) 59655972

[40] E.T. Santos, C. Alfonsín, A.J.S. Chambel, A. Fernandes, A.P. Soares Dias, C.I.C. Pinheiro, M.F. Ribeiro, Fuel 94 (2012) 624-628 